\title{
Empowering Cangkudu Village as Corporate Social Responsibilty of Bina Nusantara University
}

\author{
Ulani Yunus ${ }^{1}$, Bhernadetta Pravita Wahyuningtyas ${ }^{2,}$ Mario Nugroho W ${ }^{3,}$ Triadi Sumbogo ${ }^{2,}$ \\ Mariko Rizkiansyah ${ }^{2}$ \\ \{uyunus@binus.edu ${ }^{1}$, bhernadetta@gmail.com², triadisumbogo17@gmail.com² \\ ,mariko.rizkiansyah@gmail.com ${ }^{2}$, mario.nugroho.w@gmail.com ${ }^{3}$ \} \\ Research Interest Group Cross-Culture Communication,Bina Nusantara University,Jakarta, Indonesia ${ }^{1}$ \\ Marketing Communication Program, Communication Study Program, Faculty of Economics and \\ Communication, Bina Nusantara University,Jakarta, Indonesia ${ }^{2}$ \\ Language Center, Industrial Engineering Department and Faculty of Humanities, Bina Nusantara \\ University, Jakarta Indonesia ${ }^{3}$
}

\begin{abstract}
Cangkudu Village is located in Balaraja District, Tangerang Regency, Banten Province, and has been a partner of Bina Nusantara (Binus) University since 2017. The previous study showed that Cangkudu Village has succeed in organizational transformation because the role of Cangkudu Village Head chosen in 2013. The purpose of this study is to explore the Cangkudu Village into a pilot project as village with digital economy as Corporate Social Responsibility of Binus by comparing digital economies that have been supported in India, Kenya and France. The research method is descriptive qualitative with data sources obtained through interviews, observation and literature study. The results of the study mentioned that the five pillars needed in Cangkudu Village were the Digital Government; Digital Business; Infrastructure; Entrepreneurship Based on Innovation and Digital Skills and Values. While in Cangkudu village itself there were still stunting babies and for Tangerang Regency there were still found village in corruption due to the still limited human resources in Tangerang. Therefore Cangkudu Village needs to be fostered in the public information space and provide the application of System Information of Financial at the the village office can improve the structure of economic growth and changes in social strata in Indonesia.
\end{abstract}

Keywords: Binus, Empowering, Cangkudu Village, Corporate Social Responsibility

\section{Introduction}

Cangkudu Village in Balaraja District, Tangerang Regency, Banten Province has been a partner of Bina Nusantara (Binus) University since 2017. The results of Ulani and Team's research have been published in Scopus indexed journals [1] on managing Radio Media in Taiwan for Indonesian Workers in 2014 (Grant from Binus), the mass media that has succeeded in creating a cultural and love homeland of the special migrant female workers in Taiwan. Then also from the research results of the a grant from the ministry of research and technology Indonesia (2016 and 2017) on Effective Communication for Governance of Government Organizations related to Good Public Governance which have been disseminated into Scopus indexed journals [2]. This paper is the result of the implementation of the two studies being a community service program. The head of Cangkudu Village is Amir Hamzah was considered to bring significant changes to the Cangkudu Village administration compared to the previous administration. This research complements from the Ministry of Research, Technology, and Higher Education, Republic of Indonesia grant in 2019 which mentions the relationship between Binus and the community which is harmony, and the influence of cross communication culture 
has a relationship with an improvement of economic structure is 0.757 score. It is means the relationship is strong and close to very strong if the coefficient $>0.8$ and communication across cultures has a determination of 57.4 percent in the improvement of economy structure. So there are still 42.6 percent of other factors that influence the process. To improve the economy sturcture need transformation of the organization such as the creation of a digital economy in the village so that it becomes a pilot project for other villages to be able to prosper their citizens. Thus the research question is how to empower Cangkudu Village as Bina Nusantara University corporate social responsibility?

The research method is qualitative descriptive with data sources obtained through interviews, observations, literature studies and be backed up from the qualitative research that held in prior. We conducted interviews with the Head of Village, Village Officers, Youth Organization Members and SMEs in Cangkudu Village. The research was conducted for 7 months, from February to September 2019. Our literature study included describing the digital economy according to the World Bank, Digital Economy in Kenya, India and France.

According to the World Bank, the challenges of the digital age in developing countries are the challenges of digital infrastructure, the challenges of the digital ecosystem (human, institutions) and the inconvenience of the digital economy. As well as issues of availability and accessibility, affordability. In developing countries, for example, monthly fixed broadband prices are on average three times higher than in developed countries, and cellular broadband prices are twice as expensive. Lack of financial capital for business is a major problem for digital economic growth in developing countries. lack of initial funding can be an important obstacle because capital is needed to build product prototypes to test the commercial and technological viability of business ideas. Most developing countries lack domestic venture capital and foreign investors are usually more wary of investing in small business models that have not been proven successful (Nottebohm et al. 2012) [3]

For Kenya, the digital economy will be based on providing universal broadband everywhere that will drive digital services for the people and the digital economy. However, there were must be integration in the implementation of the digital economy. Kenya proposes five pillars as a foundation for digital economic growth. The pillars are: Digital Government; Digital Business; Infrastructure; Entrepreneurship Based on Innovation and Digital Skills and Values. Crosscutting issues that need to be considered for digital economic success . [4]

In India, electricity has not been provided for all villages. ICT which is not fully used to its full potential in India. There is a lack of ICT infrastructure in rural India. Digital cable throughout India. Currently India is discussing a digital economy that is limited because metrics of digitization such as ubiquitous, affordability, regulation, speed, use, and difficulty are difficult to obtain. Rural residents are not financially healthy enough to buy a smartphone or laptop. More intensive training for very large rural or IT communities requires account operations, conducting transactions using mobile phones, and making payments online. There is no standard operating system and this causes problems for digital empowerment because different manufacturers use different operating systems and this causes problems in data relationships in e-government applications. [5]

In France, there is a high possibility that the rise of the digital economy will support rural areas because of the high ease of IT access. Empirical investigations show a more diverse number of economic growth. The rise of tourism and vacation homes can prevent competition in IT-based industries. P. Vollaire, chairman of the software company and deputy mayor of Gap, in the French Southern Alps, considers that with 40 ski resorts in the region, it will not make people see the importance of creating new business in an IT-supported sector, they are only thinking about increasing value their real estate. This is absolutely not true. For rural areas, now 
IT is needed because the digital era is inevitable. Other types of IT-supported businesses will more favor resort businesses in French villages. [6]

\section{Digital Government in Cangkudu Village}

Based on information from the village officer, the most felt condition of the Cangkudu Village community is the improvement in the quality of public services at the village government office, including certainty in terms of service both in terms of cost and service time. Cangkudu Village has successfully implemented communication technology to support the improvement of the quality of public services but still requires an integrated information system. According to the results of discussions with the head of Cangkudu Village that the success of the innovation wants to be continued by maintaining communication in the community so that information is more quickly spread. All forms of communication, whether telegraphic, telephone, or electronic mail are clearly a problem for the organizing process. This further reinforces the central role of communication in the organization. Communication technology triggers various social transformations, including organizational transformation. As in the French, there is a great probability that the emergence of the digital economy will favor highamenity rural areas. But of course this is not enough. As mentioned in the digital economics blueprint in Kenya that in Cangkudu Village must be supported by 4 other pillars, namely: Digital Business; Infrastructure; Entrepreneurship Based on Innovation and Digital Skills and Values. Cross-cutting issues that need to be considered for digital economic success. On this occasion Binus provided training in making videos which consisted of news coverage, being a host and reporter so that it helped the public understand what innovations were being made at the Cangkudu Village office. The study showed that cross-cultural communication in Binus creates successful entrepreneurs according to the target of each group in Binus. Respondents were seen approved it as much as 54.6 percent and strongly agreed 22.2 percent. Binus is able empower the local economy with a maximum of 51 percent of respondents agreed and strongly agree 20 percent.

\section{Social Conditions in Tangerang Regency}

The District Health Office (DHO) noted that 28.8 percent of Tangerang Regency residents suffered stunting. Tangerang Regent Ahmed Zaki Iskandar admitted that there are still many children who experience stunting or malnutrition problems [7]. This can be a deep concern that can be caused by a lack of information about nutrition in the community and lack of community welfare so that there is not enough nutrition for the baby.

Stunting or shortness in children is one form of malnutrition due to the limitations of the overall socioeconomic situation in the past. Stunting is defined as an index of height according to age of less than minus two standard deviations (<-2 SD) or that toddler's height is shorter than what should be achieved at a certain age (Ministry of Health 2010 (Cahyono, Manongga, \& Picauly, 2016)). The danger of stunting in early childhood can cause a decrease in intelligence quotient (IQ), impaired psychomotor development, motor skills and neurosensory integration (Milman et al. 2005) [8]. In line with that opinion, Black et al. (2008) [8] said that nutritional problems in infants and toddlers have a major impact on development and growth in infancy and toddlers, especially in the first two years of life. Stunting toddlers are the result of chronic nutritional problems as a result of lack of food intake, coupled with infectious diseases, and environmental problems (Semba et al. 2008) [8] . This baby stunting can be caused due to lack 
of income levels as mentioned by Nottebohm et al [6]. Most developing countries lack domestic venture capital which causes MSMEs to develop their businesses less. The level of family income is calculated and compared in the form of monthly family expenses both for food and non-food expenses. The average feeding practice is probably due to the qualitative characteristics due to eating culture is almost the same, so that there is no difference in the pattern or form of behaviour of feeding practices to toddlers. Children under five in the midland ecosystem zone have the highest average love practice. This difference occurs because of environmental conditions that allow mothers to leave their children by doing other activities such as work or other activities to support their lives. This situation indicates that environmental factors as determinants of stunting do not stand alone, there are other factors that together influence stunting such as infectious diseases and parenting. Children who are often sick will affect the intake of less food so that the child's growth will be disrupted. Food intake is not the only cause of stunting, but the cause is multifactorial. Factors of poverty, population density and possible food contamination and infectious diseases can have an impact on the health status of children [8] . In addition, in Tangerang, village heads were also misused by village heads. Head of the Village Administration Division of the Tangerang Regency Community and Village Empowerment Office Ahmad Hafid acknowledged that supervision of the use of village funds was indeed weak due to the lack of human resources in the villages [9].The village government is expected to do as much as possible to prevent various acts of corruption both in terms of policy making, budget allocation and in the mechanism of policy making. Prevention of criminal acts of corruption must continue to be carried out starting from the lowest level, namely the village government so that in the future there will be a village people who are aware of the law that will increase the order of good governance. The abundance of village resources provides a significant opportunity for the village government in developing the village economy and welfare for the village community. These potentials must be properly identified and developed through continuous empowerment of the community. [10]. There are so many potentials that have not been optimally and optimally explored and have not been well managed.

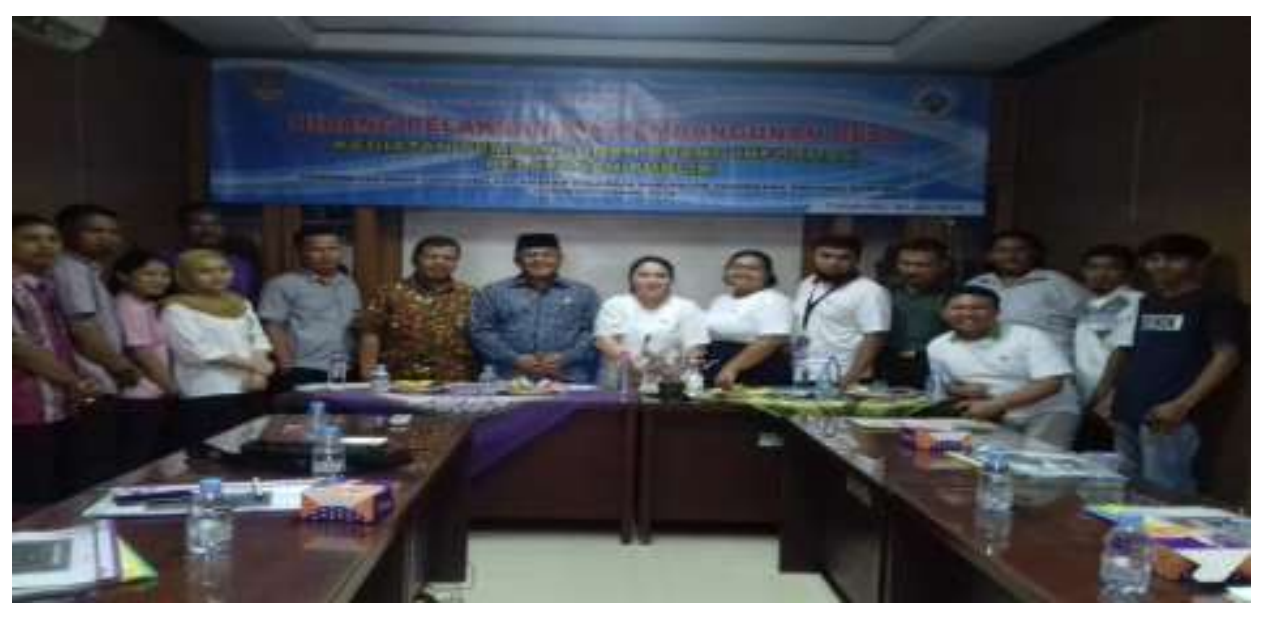

Figure 1. Empowering Cangkudu Village as The Corporate Social Responsibility 
Thus, the videos that will be made by the cangkudu's youth contain how to take care of babies so they are not stunting and also provide applications for financial management so that they become transparent and avoid potential corruption.

\section{Entrepreneurship Based on Innovation}

In Cangkudu Village, there should be innovations carried out by digital economy players so that the community has many platforms for buying and selling. For sellers, the existence of the platform makes it easy for them to find consumers. As for buyers, this convenience can be felt when they want to find items that are rarely found in conventional stores.

Through the digital economy in Cangkudu Village, MSMEs can interact directly with consumers through e-commerce that is easily accessible in Indonesia. The aim of this form of innovation is to improve the quality of life of the community so that baby stunting is no longer found, the quality of human resources increases. The existence of digital economy as an innovation in the economic field is expected to be the right solution to prosper and increase the potential of human resources in the Cangkudu Village.

One of the problems discovered through observation is the lack of information dissemination related to the socio-economic potential of the village to stakeholders and the lack of empowering MSMEs in Cangkudu Village by utilizing villages that have large factories in the vicinity. So that economic ability is uneven. The solution that can be given by the Binus Lecturer Team is the development of village communication media through village TV and the procurement of Financial Information Systems for MSMEs for the sake of economic equality and education for the residents of Cangkudu Village because there is a closeness with their citizens. This situation can be backup by result of the qualitative study that showed Binus is able enhancing local cultural value was agreed by 49.4 percent respondents and strongly agreed 21.6 percent. Binus was able to create an effective learning structure agreed by 47.6 percent and very agreed by 30.4 percent respondents. Binus is able to create people's views of Indonesia as an economically good country approved by 49.2 percent and respondents very agree as much as 26 percent. Binus is famous for its innovation of 40.8 percent agreed and more respondents strongly agreed at 42.8 percent. Four things that stand out as evidence of the growth of the economic structure in Binus environment is the amount of innovation and effective learning structure creating entrepreneurs that grow from the Binus environment as well local economic empowerment.

\section{Conclusion}

Cangkudu Village needs assistance for the realization of villages that have the potential to implement a digital economy but integration between stakeholders in Cangkudu villages such as in Kenya is the 5 pillars for the formation in Cangkudu Village were the Digital Government; Digital Business; Infrastructure; Entrepreneurship Based on Innovation and Digital Skills and Values. While in Cangkudu village itself there were still stunting babies and for Tangerang Regency there were still found village in corruption due to the still limited human resources in Tangerang. Therefore Cangkudu Village needs to be fostered in the public information space and provide the application of System Information of Financial at the the village office can improve the structure of economic growth and changes in social strata in Cangkudu Village and generally in Indonesia. 


\section{Acknowledgments}

This work is supported by: 1) the Directorate General of Strengthening for Research and Development, Ministry of Research, Technology, and Higher Education, Republic of Indonesia as a part of Penelitian Dasar Unggulan Perguruan Tinggi Research Grant to Binus University entitled "MODEL KOMUNIKASI LINTAS BUDAYA DAN DAMPAKNYA TERHADAP STRUKTUR EKONOMI DAN SOSIAL MASYARAKAT INDONESIA", with contract number: 12/AKM/PNT/2019 and contract date: 27 March 2019 and 2) Community Development Academic (CDA) of BINUS University, as Internal Grant in 2019.

\section{References}

[1] U. Yunus, H. S. Budihardjo a B. Hartanto, „Building Image of Government through Radio Taiwan International for Indonesian Female Listeners,“ Pertanika, Journal SOCIAL SCIENCES \& HUMANITIES, Vol 24, pp. 81-94, 2016.

[2] U. Yunus, S. Sari a R. P. Chairiani, „Communication Model of Governance in Jakarta, Yogyakarta and Bandung as the Process of Branding," rev. International Conference on Media, Bandung, 2016.

[3] R. Bukht a R. Heeks, Digital Economy Policy in Developing Countries, Manchester: University of Manchester, 2018.

[4] В. Маркова a V. Markova, Digital Economy, Moscow: Infra M Publication, 2018, p. DOI: 10.12737/textbook_5a97ed07408159.98683294.

[5] H. Goswami, „Opportunities And Challenges Of Digital India Programme“, International Education \& Research Journal, pp. 78-79, 2016.

[6] B. Moriset, „Developing the digital economy in France's rural regions: A new era for telecenters?.,“ Annual Meeting, Association of American Geographers, Washington D.C, 2010.

[7] B. Adji , „Republika.co.id,“ 30 January 2019. [Online]. Available: https://www.republika.co.id.

[8] F. Cahyono, S. . P. Manongga a I. Picauly, „Faktor Penentu Stunting Anak Balita Pada Berbagai Zona Ekosistem Di Kabupaten Kupang,“J. Gizi Pangan, Volume 11, Nomor 1, Maret, pp. 9-18, 2016.

[9] W. Bogiarto, „Rmoljakarta.com,“ 8 July 2019. [Online]. Available: http://www.rmoljakarta.com.

[10] Y. Kadir a R. M. Moonti, „Pencegahan Korupsi Dalam Pengelolaan Dana Desa,“ Jurnal IUS, ISSN 2303-3827, 2017. 